\title{
Association of HbA1c Level with Lipid Profiles among Type 2 Diabetic Patients attended at Medical University of Bangladesh
}

\author{
Moitreyee Majumder ${ }^{1}$, Forhadul Hoque Mollah $^{2}$, Shamim Ara Ferdous ${ }^{3}$ \\ ${ }^{1}$ Associate Professor, Department of Biochemistry, Shaheed Suhrawardy Medical College, Dhaka, Bangladesh; \\ ${ }^{2}$ Professor, Department of Biochemistry, Bangabandhu Sheikh Mujib Medical University, Dhaka, \\ Bangladesh; ${ }^{3}$ Lecturer, Department of Biochemistry, Shaheed Suhrawardy Medical College, \\ Dhaka, Bangladesh
}

[Received: 12 October 2018; Accepted: 2 November; Published: 1 January 2019]

\begin{abstract}
Background: Type 2 diabetic patients are presented with dyslipidemia. Objective: The objective of this study was to see the association between the HbAlc and lipid profiles among the diabetic subjects. Methodology: The cross-sectional study was carried in the Department of Biochemistry at Bangabandhu Sheikh Mujib Medical University (BSMMU), Dhaka, Bangladesh on type 2 diabetic individual attending the endocrine OPD of BSMMU. In this study estimation of $\mathrm{HbAlc}$ level and lipid profiles in diabetic subjects were performed and was compared the lipid profiles between the controlled $(\mathrm{HbA} 1 \mathrm{c}<7 \%)$ and uncontrolled (HbA1c $>7 \%$ ) groups. Result: A total number of 95 patients were recruited for this study. The mean age of the respondents was $42.63 \pm 5.56$ years. Female $(8.21 \pm 1.88)$ had lower HbAlc than male $(8.42 \pm 2.21)$ in the study. TC: HDL $(6.07 \pm 1.02: 1)$ and LDL: HDL $(3.88 \pm 1.58: 1)$ were also higher. Among the study population 30 had good ( $\mathrm{HbA} 1 \mathrm{c}<7 \mathrm{mg} \%)$ glycemic control and 14 of them were male and 16 were female. Those having good glycemic control had lower TG and HDL $(176.72 \pm 88.83$ vs $206.84 \pm 124.77 \mathrm{mg} / \mathrm{dl})$ and $(32.84 \pm 7.78 \mathrm{vs}$ $34.88 \pm 8.48 \mathrm{mg} / \mathrm{dl})$; however, higher TC and LDL (201.56 $\pm 34.73 \mathrm{vs} 197.19 \mathrm{mg} / \mathrm{dL})$ and $(133.04 \pm 33.71 \mathrm{vs}$ $124.30 \pm 35.97 \mathrm{mg} / \mathrm{dL}$ ) than those having poor glycemic control. No statistically significant difference between these two groups were observed. Conclusion: Thus there is no statistical significant difference between $\mathrm{HbAlc}$ and lipid profile among type 2 diabetes mellitus patients. [Journal of National Institute of Neurosciences Bangladesh, 2019;5(1):72-75]
\end{abstract}

Keywords: Diabetes Mellitus; Glycemic control; lipid profile

Correspondence: Dr. Moitreyee Majumder, Department of Biochemistry, Shaheed Suhrawardy Medical College, Dhaka, Bangladesh; Cell no.: +8801712109664; Email: moitreyeemajumder@gmail.com

Conflict of interest: There is no conflict of interest relevant to this paper to disclose.

Funding agency: This research project was not funded by any group or any institute.

Contribution to authors: Majumder M, Mollah FH, involved in protocol preparation, data collection and literature search up to manuscript writing. Majumder M \& Ferdous SA involved in preparation and revision of this manuscript.

How to cite this article: Majumder M, Mollah FH, Ferdous SA. Association of HbA1c Level with Lipid Profiles among Type 2 Diabetic Patients attended at Medical University of Bangladesh. J NatlInstNeurosci Bangladesh, 2019; 5(1): 72-75

Copyright: (C2019. Majumder et al. Published by Journal of national institute of Neurosciences Bangladesh. This article is published under the creative commons CC-BY- NC License (https://creativecommons.org/licenses/by-nc/4.0/). This license permits use, distribution and reproduction in any medium, provided the original work is properly cited, and is not used for commercial purposes.

\section{Introduction}

Hyperglycemia is considered a primary cause of diabetic vascular complications. The increased amount and duration of glucose in the blood allows more glycosylation to occur, not only with haemoglobin, but also with proteins and attributes to the formation of sugar-derived substances called advanced glycation end products (AGEs). Increased AGE accumulation in the diabetic vascular tissues has been associated with changes in endothelial cell, macrophage, and smooth muscle cell function ${ }^{1-2}$.

Hyperglycemia is associated with oxidative stress, impaired trace element and lipid metabolism as well as pancreatic enzyme abnormalities ${ }^{3-4}$. To prevent microvascular complications of diabetes, American College of Physicians recommends the goal for glycemic control should be as low as is feasible without undue risk for adverse events or an unacceptable burden on patients. A hemoglobin A1c level less than $7 \%$ based on individualized assessment is a reasonable goal for many but not all patients. Further research to assess the optimal level of glycemic control, particularly in the presence of comorbid conditions is recommended ${ }^{5}$.

Dyslipidemia is one of the major risk factors for 
cardiovascular disease in diabetes mellitus. The characteristic features of diabetic dyslipidemia are a high plasma triglyceride concentration, low HDL cholesterol concentration and increased concentration of small dense LDL-cholesterol particles. The lipid changes associated with diabetes mellitusare attributed to increased free fatty acid flux secondary to insulin resistance ${ }^{6}$.

As elevated $\mathrm{HbAlc}$ and dyslipidemia are independent risk factors of CVD, diabetic patients with elevated $\mathrm{HbAlc}$ and dyslipidemia can be considered as a very high risk group for CVD. An increase in $1.0 \%$ in HbAlc was found associated with a $28.0 \%(\mathrm{p}<0.002)$ increase in risk of death ${ }^{7}$. Improving glycemic control can substantially reduce the risk of cardiovascular events in diabetics $^{8}$. It has been estimated that reducing $\mathrm{HbAlc}$ levels by $0.2 \%$ could lower the mortality by $10.0 \%{ }^{7}$.

The study was carried out to estimate $\mathrm{HbAlc}$, and lipid profiles in controlled and uncontrolled diabetic subjects and to compare the lipid profiles between controlled diabetic subjects $(\mathrm{HbA} 1 \mathrm{c}<7 \%)$ and uncontrolled diabetic subjects $(\mathrm{HbAlc}>7 \%)$, so that baseline information can be obtained and preventive measures can be taken at an early stage.

\section{Methodology}

This cross-sectional study was conducted in the Department of Biochemistry at Bangabandhu Sheikh Mujib Medical University (BSMMU), Dhaka, Bangladesh from July 2011 to June 2013 for a period of two (02) years. Sample was collected from type 2 diabetic patients aged between 30 to 70 years attending the Endocrinology department of BSMMU. Study subjects were selected by purposive sampling. Ethical clearance was taken from Institutional Review Board of BSMMU prior to the work. Pregnant women, patients suffering from hypothyroidism, known heart disease or from diabetic nephropathy were excluded from the study. According to the hospital records patients were primarily selected. Patient was diagnosed as diabetic if fasting plasma glucose level was $>7.0 \mathrm{mmol} / \mathrm{L}$ (126 $\mathrm{mg} / \mathrm{dl})$. After enrollment, purpose and procedure of the study was explained in details and informed written consent was taken from all study subjects. With all aseptic precaution $10 \mathrm{ml}$ of venous blood was drawn from anticubital vein after overnight fasting (12 hrs) in a disposable plastic syringe; it was delivered into a properly labeled clean dry test tube and kept in standing position till clot formation. Then serum was separated by centrifuging at $3000 \mathrm{rpm}$ for 5 minutes. For HbAlc $3 \mathrm{ml}$ whole blood was taken in vacuum collection tube containing EDTA. Estimation of serum glucose concentration was done by Glucose oxidase (GOD-PAP) method, fasting total cholesterol by CHOL method, fasting Triglyceride by TGL method, fasting HDL by AHDL method (Siemens Healthcare Diagnostics Inc 2008); fasting LDL was calculated by using Friedewald's formula. Estimation of $\mathrm{HbAlc}$ was done Ion exchange HPLC ${ }^{9}$. Analysis was done in the Department of Biochemistry, BSMMU. Adult normal Serum level of fasting blood glucose was 3.6-6.1 $\mathrm{mmol} / \mathrm{L}, \mathrm{HbA} 1 \mathrm{C}:<6 \%$. For serum lipid reference level, according to National Cholesterol Education Programme (NCEP) Adult Treatment Panel III (ATP III) guideline: $\quad \mathrm{TG} \geq 150 \mathrm{mg} / \mathrm{dl}, \quad \mathrm{LDL}>130 \mathrm{mg} / \mathrm{dl}, \quad \mathrm{TC}>200$ $\mathrm{mg} / \mathrm{dl}, \mathrm{HDL}<40 \mathrm{mg} / \mathrm{dl}$ (male) and $<50 \mathrm{mg} / \mathrm{dl}$ (female); Dyslipidemia was defined by presence of one or more than one abnormal serum lipid concentration ${ }^{10}$. The patients were classified into two groups depending on their glycated hemoglobin (HbA1c); Good Glycemic Control (GGC) group having $\mathrm{HbA} 1 \mathrm{c}<7.0 \%$ and Poor Glycemic Control (PGC) group having $\mathrm{HbA} 1 \mathrm{c} \geq 7.0 \%{ }^{10}$. After data collection they were checked, cleaned and edited for any discrepency. Data were analysed using SPSS-16. t-test, pearsons correlation test were done. Data were presented in the form of tables.

\section{Results}

Among the 95 respondents 44 (47.4\%) were male and $51(52.6 \%)$ were female. Age of the respondents was between 30-50 years with mean age (years) $42.63 \pm 5.56$. HbA1C $(\mathrm{mg} \%)$ was increased $(8.31 \pm 2.04)$ in the study population. Mean serum total cholesterol and LDL $(198.34 \pm 39.62 \& 126.75 \pm 35.38 \mathrm{mg} \%) \quad$ was within normal limit in the study population. Other components of lipid profile i.e. TAG $(198.91 \pm 116.71$ $\mathrm{mg} / \mathrm{dl})$ and HDL $(34.35 \pm 8.31 \mathrm{mg} / \mathrm{dl})$ were beyond normal range. TC: HDL $(6.07 \pm 1.02: 1)$ and LDL: HDL $(3.88 \pm 1.58: 1)$ were also higher (Table 1$)$.

Table 1: Biochemical Parameters of the Study Subjects $(\mathrm{n}=95)$

\begin{tabular}{lc}
\hline Parameters & Mean \pm SD \\
\hline TC $(\mathrm{mg} / \mathrm{dl})$ & $198.34 \pm 39.62$ \\
TAG $(\mathrm{mg} / \mathrm{dl})$ & $198.91 \pm 116.71$ \\
$\mathrm{LDL}(\mathrm{mg} / \mathrm{dl})$ & $126.75 \pm 35.38$ \\
$\mathrm{HDL}(\mathrm{mg} / \mathrm{dl})$ & $34.35 \pm 8.31$ \\
$\mathrm{TC}: \mathrm{HDL}$ & $6.07 \pm 1.92: 1$ \\
$\mathrm{LDL}: \mathrm{HDL}$ & $3.88 \pm 1.58: 1$ \\
$\mathrm{HbA} 1 \mathrm{C}(\%)$ & $8.31 \pm 2.04$ \\
\hline
\end{tabular}


Female had lower HbA1c than male in the study (Male vs. Female $8.42 \pm 2.21$ vs $8.21 \pm 1.88 \mathrm{mg} \%$ ) (Table 2).

Table 2: Sex distribution of the study population according to glycemic control

\begin{tabular}{lcc}
\hline Paremeters & Male $(\mathbf{n}=\mathbf{4 4})$ & Female $(\mathbf{n}=\mathbf{5 1})$ \\
\hline HbA1c $(\%)$ & $8.42 \pm 2.21$ & $8.21 \pm 1.88$ \\
\hline
\end{tabular}

Considering the lipid profile female had higher HDL than male (M vs. F $32.76 \pm 8.41$ vs. $35.57 \pm 7.97$ ). But other components of lipid profile were also higher in female. TC, TAG, LDL \& HDL $(\mathrm{mg} / \mathrm{dl})$ in male and female were $189.41 \pm 37.71$ vs. $203.43 \pm 40.31$, $186.72 \pm 111.75$ vs. $207.14 \pm 119.9,121.59 \pm 31.02$ vs. $129.13 \pm 38.12$ and $32.76 \pm 8.41$ vs. $35.57 \pm 7.97$ ) respectively. Lipid ratios i.e TC: HDL and LDL: HDL were also higher in female ( $\mathrm{M}$ vs $\mathrm{F} 6.04 \pm 1.61: 1 \mathrm{vs}$

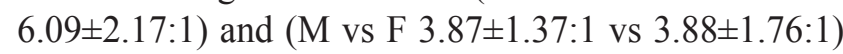
respectively (Table 3 ).

Table 3: Sex distribution of the study population according to lipid profile

\begin{tabular}{lcc}
\hline Parameters & Male(n=44) & Female(n=51) \\
\hline TC $(\mathrm{mg} / \mathrm{dl})$ & $189.41 \pm 37.71$ & $203.43 \pm 40.31$ \\
TG $(\mathrm{mg} / \mathrm{dl})$ & $186.72 \pm 111.75$ & $207.14 \pm 119.9$ \\
LDL $(\mathrm{mg} / \mathrm{dl})$ & $121.59 \pm 31.02$ & $129.13 \pm 38.12$ \\
HDL $(\mathrm{mg} / \mathrm{dl})$ & $32.76 \pm 8.41$ & $35.57 \pm 7.97$ \\
TC:HDL & $6.04 \pm 1.61$ & $6.09 \pm 2.17$ \\
LDL:HDL & $3.87 \pm 1.37$ & $3.88 \pm 1.76$ \\
\hline
\end{tabular}

Among the study population 30 had good $(\mathrm{HbA} 1 \mathrm{c}<7$ $\mathrm{mg} \%$ ) glycemic control. 14 of them are male and 16 are female (Table 4).

Table 4: Distribution of study population by glycemic control

\begin{tabular}{lccc}
\hline Glycemic Control & Male & Female & Total \\
\hline $\mathrm{HbA} 1 \mathrm{c}<7 \mathrm{mg} \%$ & $14(\%)$ & $16(\%)$ & $30(\%)$ \\
$\mathrm{HbA} 1 \mathrm{c}>7 \mathrm{mg} \%$ & $30(\%)$ & $35(\%)$ & $65(\%)$ \\
Total & $\mathbf{4 4 ( \% )}$ & $\mathbf{5 1 ( \% )}$ & $\mathbf{9 5 ( \% )}$ \\
\hline
\end{tabular}

Those having good glycemic control had lower TG \& HDL $(176.72 \pm 88.83$ vs $206.84 \pm 124.77 \mathrm{mg} / \mathrm{dl})$ and (32.84 \pm 7.78 vs $34.88 \pm 8.48 \mathrm{mg} / \mathrm{dl}$ ); however, higher TC and LDL $(201.56 \pm 34.73$ vs $197.19 \mathrm{mg} / \mathrm{dl})$ and $(133.04 \pm 33.71$ vs $124.30 \pm 35.97 \mathrm{mg} / \mathrm{dl})$ than those having poor glycemic control. No statistically significant difference between these two groups were observed by unpaired t-test (Table 5).

Table 5: Relation of glycemic control with Lipid Profile

\begin{tabular}{lccc}
\hline Parameters & $\begin{array}{c}\text { HbA1c }<\text { 7mg\% } \\
(\mathbf{n}=\mathbf{3 0})\end{array}$ & $\begin{array}{c}\text { HbA1c } \geq 7 \mathbf{m g} \% \\
(\mathbf{n}=\mathbf{6 5})\end{array}$ & P value \\
\hline TC $(\mathrm{mg} / \mathrm{dl})$ & $201.56 \pm 34.73$ & $197.19 \pm 41.40$ & 0.638 \\
TG $(\mathrm{mg} / \mathrm{dl})$ & $176.72 \pm 88.83$ & $206.84 \pm 124.77$ & 0.270 \\
LDL $(\mathrm{mg} / \mathrm{dl})$ & $133.04 \pm 33.71$ & $124.30 \pm 35.97$ & 0.297 \\
HDL $(\mathrm{mg} / \mathrm{dl})$ & $32.84 \pm 7.78$ & $34.88 \pm 8.48$ & 0.293 \\
\hline
\end{tabular}

No significant correlation was observed between HbA1c and lipid profile by Pearson's correlation (Table 6).

Table 6: Correlation of lipid profile with $\mathrm{HbA1c}$

\begin{tabular}{lcc}
\hline Biochemical & \multicolumn{2}{c}{ HbA1c } \\
\cline { 2 - 3 } parameters & r & P value \\
\hline TC $(\mathrm{mg} / \mathrm{dl})$ & -0.04 & 0.70 \\
TG $(\mathrm{mg} / \mathrm{dl})$ & 0.165 & 0.111 \\
LDL $(\mathrm{mg} / \mathrm{dl})$ & -0.055 & 0.608 \\
HDL $(\mathrm{mg} / \mathrm{dl})$ & 0.071 & 0.494 \\
TC $:$ HDL & 0.098 & 0.346 \\
LDL $:$ HDL & 0.057 & 0.599 \\
\hline
\end{tabular}

' $r$ ' value is obtained by pearsons correlation

\section{Discussion}

In our study age of the respondents was between 30-50 years with mean age (yrs) 42.63 \pm 5.56 . Among the 95 respondents $44(47.4 \%)$ were male and 51(52.6\%) were female. A study in Punjab by Singh and Kumar ${ }^{11}$ in 2011 found higher mean age ( $50.3 \pm 11.8$ years).

Mean value of $\mathrm{HbAlc}$ was $8.31 \pm 2.04 \mathrm{mg} \%$ in our study (Male vs. Female $8.42 \pm 2.21$ vs $8.21 \pm 1.88 \mathrm{mg} \%$ ). A study in India showed by Shinghet al ${ }^{12}$ had similar HbAlc (Male vs. Female $8.21 \pm 2.16$ Vs $8.44 \pm 2.34$ ). Another study in Punjab ${ }^{11}$ revealed lower mean HbAlc $(7.34 \pm 1.24 \%)$. A study in Nepal by Mahatoet $\mathrm{al}^{10}$ found lower mean in male and female respectively $(7.20 \pm 0.10$ vs $7.53 \pm 0.17$.)

Mean serum total cholesterol and LDL (198.34 \pm 39.62 \& $126.75 \pm 35.38 \mathrm{mg} \%$ ) was within normal limit in this study population. Other components of lipid profile like TAG $(198.91 \pm 116.71 \mathrm{mg} / \mathrm{dL})$ and HDL $(34.35 \pm 8.31 \mathrm{mg} / \mathrm{dL})$ were beyond normal range. Mahatoet $\mathrm{al}^{10}$ and Charitha et $\mathrm{a} \mathrm{l}^{18}$ found lower HDL and significantly higher TC, TAG and LDL in their study. Singh $\mathrm{G}^{11}$ found higher TC $(203.9 \pm 15.8 \mathrm{mg} / \mathrm{dl})$, lower TAG $(151.1 \pm 17.7 \mathrm{mg} / \mathrm{dl}), \operatorname{HDL}(37.7 \pm 6.2 \mathrm{mg} / \mathrm{dl})$ and 
LDL $(124.4 \pm 11.9 \mathrm{mg} / \mathrm{dl})$ in their study was similar to our study.

Components of lipid profile and lipid ratios were relatively high in female in our study which is consistent with the study by Singh et $\mathrm{al}^{12}$ in Tamil Nadu, India. Mahatoet $\mathrm{a}^{10}$ and his co-worker in 2011 also had higher lipid profiles in female except TAG.

Though non-significant, TAG and HDL is relatively high and TC and LDL are relatively low in poorly controlled group in our study. On the other hand Singh et $\mathrm{al}^{12}$ found that lipid profile parameters (except HDL) were found to be increased significantly in uncontrolled diabetics. Khawet $\mathrm{al}^{7}$ also reported that severity of dyslipidemia increases in patients with higher $\mathrm{HbAlc}$ value. Study by Sheikhpouret $\mathrm{al}^{14}$ in 2013 did not reveal any significant relationship between glycemic control and lipid profile, which is consistent with our study. The findings of this study thus are consistent with some studies, and on the other hand inconsistent with some other studies.

As elevated $\mathrm{HbAlc}$ and dyslipidemia are independent risk factors of CVD, diabetic patients with both elevated $\mathrm{HbA} 1 \mathrm{c}$ and dyslipidemia can be considered as a very high risk group for CVD. Thus HbA1c \& lipid profile can be used as individual marker of glycemic control and dyslipidemia in type 2 diabetes mellitus.

\section{Conclusion}

Overall glycemic control of the patients is poor. But female has relatively better glycemic control than male counterpart. Components of lipid profile except TAG is within normal range. Patients with good glycemic control have lower TAG \& HDL. Patients with poor glycemic control have higher TC \& LDL. As the study result does not reveal any significant relationship between glycemic control and lipid profile, which is consistent with some studies, and on the other hand inconsistent with some other studies, another multi-centered study with large sample size can be done.

\section{References}

1. Martinim AC, Sanders RA, Atkins JB. Diabetes, oxidative stress and antioxidants- A review. J Biochem\&MolToxicol. 2003;17: 24-38.

2. Ajay K. Coronary artery disease and diabetes. Cardiol-ogyToday. 2001; 4: 221-224.

3. Abou-Seif MA, Youssef A. Evaluation of some biochemical changes in diabetic patients ClinicaChimicaActa. 2004;346:161-170.

4. Abdella NA, Mojiminiyi OA, Akanji AO and Moussa MA .Associations of plasma homocysteine concentration in subjects with type 2 diabetes mellitus. ActaDiabetol, 2002;39(4):183-90.

5. Qaseem A, Vijan S, Snow V, Cross JT, Weiss KB, Owens DK. Glycemic Control and Type 2 Diabetes Mellitus: The Optimal Hemoglobin A1c Targets. A Guidance Statement from the American College of Physicians, Ann Intern Med. 2007;147: 417-422.

6. Mooradian AD. Dyslipidemia in type 2 diabetes mellitus, Nature Clinical Practice, Endocrinology \& Metabolism. 2009; 5(3).

7. Khaw KT, Wareham N, Luben R, Bingham S, Oakes S, Welch A, et al. Glycatedhaemoglobin, diabetes, and mortality in men in Norfolk cohort of European Prospective Investigation of Cancer and Nutrition (EPIC-Norfolk). Br Med J 2001; 322: 15-18

8. Selvin E, Coresh J, Brancati FL. The burden and Treatment of Diabetes in elderly individuals in the US.Diabetic Care 2006 Nov 29(11):2415-19

9. Hoogeveen EK, KostensePk, Jakobs C, Dekker JM, Nijpels G, Heine RJ, et al. Hyperhomocysteinemia increase risk of death, especially in type 2 diabetes : A 5 year follow up of Hoorn Study, Circulation. 2000; 101: 1501-1506

10. Mahato RV, Gyawali P, Raut PP,Regmi et al. Association between glycaemic control and serum lipid profile in type 2 diabetic patients: Glycatedhaemoglobin as a dual biomarker. Biomedical Research. 2011; 22 (3): 375-380

11. Singh G, Kumar A. Relationship among HbA1c and Lipid Profile in Punajbi Type 2 Diabetic Population. Journal of Exercise Science and Physiotherapy2011;7(2): 99-102,

12. Singh P, Arumalla VK, Rajagopalan B. Comparison of Lipid Profile between Controlled and Uncontrolled Type - 2 Diabetic Subjects. Research and Reviews: Journal of Medical and Health Sciences 2013;2(4):69-72

13. Charitha B, Arul Senghor R, MeeraShivashekar, Ebenezer William .Glycated Hemoglobin as a Dual Marker: In Control of Glycemic Status and Diabetic Dyslipidemia International Journal of Pharmaceutical and Clinical Research 2013; 5(3): 111- 113

14. RobabSheikhpour, FatemehSadeghian, Fatemehpourhosseini, ShokouhRajabi. Correlation between Glycated Hemoglobin, Serum Glucose and Serum Lipid Levels in Type 2 Diabetes. Iranian Journal Of Diabetes And Obesity 2013;5(1): 12-15 